\title{
TEMA-TEMA TABLIGH YANG BERKAITAN DENGAN SOCIAL CAPITAL MASYARAKAT KOTA PADANG
}

\author{
Nazirman \\ Abdul Manan \\ (Fakultas Dakwah dan IImu Komunikasi IAIN Imam Bonjol. \\ Email: nazirmanma@gamail.com, jalanku.1000@gmail.com )
}

\begin{abstract}
Penelitian ini mengkaji tema-tema tabligh yang diangkatkan oleh para mubaligh yang erat kaitannya dengan modal sosial (social capital) masyarakat kota Padang. Penelitian ini berangkat dari fenomena sosial masyarakat kota Padang yang menjadi bagian dari masyarakat Sumatera Barat (Minangkabau) yang berfalsafah adat basandi syara', syara' basandi kitabullah. Disamping itu ungkapan kok barek samo dipikua, ringan samo dijinjiang menggambarkan bahwa masyarakat Minagkabau termasuk Padang memiliki karakter yang sejalan dengan agama Islam dan memiliki modal sosial yang cukup tinggi sebagai modal pembangunan di berbagai sektor. Kondisi ini perlu dipertahankan karena ada kecenderungan mulai menipis dan tinggal selogan saja. Oleh karena itu penelitian mempertanyakan dan menjawab bagaimana proses penyajian tema yang diangkat oleh mubaligh yang berkaitan dengan modal sosial. Lebih dari itu pertanyaan penelitian ini diarbkan kepada tematema, metode dan pedekatan serta alasan para mubaligh menyajikan tema tablighnya. Untuk menemukan dan menjawab pertanyaan penelitian tersebut digunakan metode kualitatifpendekatan deskriptif. Kemudian teori dan konsep yang dipakai dalam penelitian ini menggunakan teori komunikasi-effek komunikasi, teori pengembangan masyarakat Islam dan konsep-konsep dakwah itu sendiri. Hasil penelitian ini menemukan bahwa secara umum tema yang diangkat oleh para mubaligh meliputi hidup tolong-menolong, kerjasama dan membiasakan hidup berbagi. Metode dan pendekatan yang digunakan dalam penyajian pesan lebih didominasi oleh metode dialogis, monologis dan pratik langsung. Alasan pemilihan dan penetapan tema dalam tabligh secara umum para mubaligh didasari oleh hasil observasi, permintaan langsung dari jamaah serta kemauan dari mubaligh itu sendiri (inisiatif mubaligh).
\end{abstract}

Kata Kunci: Tablig, Sosial Capital, Tema, Metode

\section{PENDAHULUAN}

Secara kultur masyarakat kota Padang merupakan bagian dari masyarakat Sumatera Barat (Minangkabau) yang memiliki slogan hidup Adaik basandi syara' syara' basandi Kitabullah, syara' magato adaik mamakai. "Saciok bak anak ayam sadancing bak basi, barek samo dipikua, ringan samo dijinjiang, Sahilia samudiak, saayun salangkah. Bahkan sering pula diungkapkan "duduk surang basampik-sampik duduak basamo balapang-lapang. Indak ado samo dicari, ado samo dimakan.
Ungkapan-ungkapan ini menjadi simbul perekat dan cita-cita ideal masyarakat Sumatera Barat khusunya Padang yang menggambarkan cara dan karakter hidup keseharian masyarakat dalam membangun. Ini menjadi modal awal dalam pembangunan baik bersifat fisik, mental maupun aspek sosial.

Modal sosial (social capital) merupakan sebagai serangkaian nilai dan norma informal yang dimiliki bersama diantara anggota suatu kelompok masyarakat yang memungkinkan terjadinya kerjasama meliputi Trust (keper- 
cayaan), reciprocal (hubungan timbal balik), dan interaksi sosial. Trust (ke-percayaan) dapat mendorong seseorang untuk bekerjasama dengan orang lain dalam memunculkan aktivitas ataupun tindakan bersama yang produktif.

Mantan Menteri Sosial RI Salim Segaf Aljufri, pada saat kunjungan kerja ke Provinsi Sumatera Barat pada Tahun 2014 dalam kegiatan peresmian bedah rumah di Kelurahan Olo Kecamatan Padang Barat kota Padang, sebagaimana dilansir oleh Harian Umum Haluan dan dimuat pada harianhaluan.com mengatakan rasa kepedulian sosial masyarakat saat ini semakin menipis. Jika bertemu seseorang ditabrak mobil misalnya, maka seseorang yang melihatnya akan berfikir, ah ...... biar saja toh dia bukan keluarga saya, bukan anak saya. Jika seseorang kesulitan, tak punya makanan yang akan dia makan hari ini, tak ada masyarakat sekitarnya yang peduli, tak ada yang membantu. Hal ini merupakan salah satu alasan yang menyebabkan mereka turun ke jalan menjadi pengemis.

Mubaligh menjadi orang yang berperan dalam mengembalikan serta memotivasi umat untuk melestarikan nilai-nilai luhur yang mulai dirasakan menipis dalam kehidupan bermasyarakat. Kegiatan ini dapat dilaksanakan melalui khutbah, ceramah dan wirid pengajian yang terjadwal di berbagai masjid. Berdasarkan hal di atas, menarik untuk dicermati lebih jauh arah, strategi dan materi tabligh para mubaligh di kota Padang yang berkaiatan dengan social capital (modal sosial) masyarakat.

Secara umum penelitian ini mempertanyakan bagaimana format tabligh yang berkaitan dengan modal sosial (social capital) masyarakat kota Padang. Secara khusus pertanyaan penelitian ini mengacu kepada tema, metode dan pendekatan serta alasan pemilihan tema oleh para mubaligh. Penelitian ini bertujuan untuk megetahui dan memahami tema-tema, materi, metode dan pendekatan serta alasan para mubaligh memilih dan metetapkan tema-tema tabligh yang relevan dengan modal sosial (social capital).

Secara konsep, tabligh diartikan sebagai proses penyampaian (transmisi dan informasi) ajaran Islam kepada manusia yang bersifat menggugah dan merubah tatanan kehidupan ke arah petunjuk dan kebahagiaan sesuai dengan kadar kemampuan penerima pesan dakwah. Tentunya perubahan ke arah perbaikan umat sangat tergantung pada kemampuan para mubaligh dalam mendigsain dan menyajikan materi tablighnya sesuai dengan tema-tema yang aktual dan dibutuhkan oleh masyarakat.

Acep Aripudin mejelaskan bahwa tabligh merupakan salah satu metode dan pendekatan dalam berdakwah yang mengisi ruang-ruang praktik dakwah yang berorientasi pada ajakan berdasar keterampilan lisan dan kemampuan retorika mubaligh. Dalam tabligh materi yang disampaiakn bersifat deduktif dan menghindari pesan-pesan dakwah yang berat seperti penyederhanaan suatu pegertian atau makna dan berorientasi pada perubahan umat secara lebih praktis (Acep Aripuddin, 2014: 123)

Karena tabligh pada hakikatnya suatu proses pemberian informasi dan penyebarluasan ajaran Islam kepada masyarakat yang menuntut sebuah perge-rakan dan usaha perbaikan ke arah lebih baik, maka signifikansi penelitian ini adalah mencari dan menemukan formulasi, tema-tema dan teknik yang digunakan oleh para mubaligh dalam berdakwah 
melalui tabligh yang berkaitan dengan social capital (modal sosial) masyarakat di kota Padang.

Kajian ini berkaitan dengan riset sebelumya atau studi literatur terkait dengan penelitian tentang Materi Khutbah Jum at yang disampaikan oleh para khatib di Kota Padang yang diteliti oleh Sarwan dkk (2013). Penelitiannya fokus kepada materi khutbah yang disampaikan oleh para khatib pada hari Jum at di berbagai Masjid di Kota Padang. Adapun hasil temuannya mengungkapkan bahwa secara umum orientasi khutbah masih di sekitar masalah sosial kemasyarakatan yang bersifat normatif. Pada bagian saran penelitian peneliti menyarakan agar pengurus masjid menentukan topik (tema) khutbah Jum 'at di tempat masing-masing sesuai dengan permasalahan umum yang dihadapi oleh jamaah baik masalah agama maupun masalah sosial dalam kehidupan sehari-hari.

Sementara penelitian ini menfokuskan kepada tema-tema tabligh yang berorientasi pada social capital (modal sosial) masyarakat yang disampaikan mubaligh dalam kegiatan tablighnya. Secara konsep modal sosial ini mengakaji bahwa pembangunan suatu masyarakat dimulai dari pembangunan sumber daya manusia, daya kelompok yang berusaha bersama di setiap masyarakat yang ditunjang oleh nilai-nilai yang disepakati untuk menuju sebuah perubahan, kohesi sosial, trust, resiprokal, partisifasi, eksternalitas dan digerakkan melalui variasi jaringan.

Dengan demikian social capital (modal sosial) dapat diindikatorkan sebagai berikut :

1. Kelompok Sosial/Kelembagaan

2. Trust/Kepercayaan dan Solidaritas

3. Tindakan bersama (colective action)
4. Informasi dan komunikasi

5. Partisipasi dan kerjasama

6. Pemberdayaan dan pembinaan pemerintah

Dari keenam indikator ini mubaligh menjadi bagian yang tidak terpisahkan dari sebuah proses pengenalan, pemahaman materi bagi masyarakat yang berhubungan dengan social capital melalui informasi dan komunikasi(tabligh). Oleh karena itu teori dan konsep yang digunakan dalam penelitian ini menggunakan teori-teori komunikasi, teori pemberdayaan masyarakat Islam yang dianggap bersentuhan dengan apa yang mau dipersoalkan dalam riset ini.

\section{KOMUNIKASI DAN PEMBERDAYAAN MASYARAKAT ISLAM; SEBUAH TINJAUAN TEORITIS}

Secara teori sebuah komunikasi dinilai efektif bila ransangan yang disampaikan dan yang dimaksud oleh sumber berkaitan erat dengan ransangan yang ditangkap dan dipahami oleh penerima (Goyer: 1970). Gonzalez dalam Jahi sebagaimana yang dikutip oleh Rochajat Harun dan Elvinaro Ardianto, mengemukakan bahwa efek komunikasi terbagi kepada tiga hal yaitu kognitif, afektifdan konatif. Efek kognitif meliputi peningkatan kesadaran belajar, dan tambahan pengetahuan. Efek afektif berhubungan dengan emosi, perasaan, dan sikap, sedangkan efek konatif berhubungan dengan perilaku dan niat untuk melakukan sesuatu menurut cara tertentu. Ketiga aspek ini saling berhubungan dan ketiga aspek ini juga indevenden satu sama lain. Contoh meningkatnya pengetahuan tentang sesuatu isu tidak selalu diikuti oleh perubahan sikap (Rochajat Harun dkk, 2011: 110). 
Amin Abdullah, sebagaimana yang dikutip oleh Nanih, mengungkapkan bahwa pengembangan masyarakat Islam adalah sistem tindakan nyata yang menawarkan alternatif model pemecahan masalah ummah dalam bidang sosial, ekonomi, dan lingkungan dalam perspektif Islam. Kemudian Nanih mengungkap-kan bahwa PMI (Pengembangan Masyarakat Islam) adalah sebuah transformasi dan pelembagaan ajaran Islam ke dunia realitas melalui penyampaikan konsepsi Islam mengenai kehidupan sosial, ekonomi, pemeliharaan lingkungan hidup, penggalangan ukhuwah islamiyah, menjalin dan mewujudkan $\mathrm{MoU}$, riset potensi lokal, katalisasi aspirasi dan kebutuhan umat, konsultasi, pendampingan hal teknis, penyusunan rencana, aksi sosial dan pemecahan masalah serta stabilitasi (Nanih Machendraty, 2001: 20)

Tabligh dapat dimaknai sebagai bahagian dari komunikasi. Tabligh secara konseptual dipahami sabagai salah satu cara yang dilakukan oleh Rasul dalam menjalankan misi kerasulannya yaitu berdakwah. Dakwah jika dilihat dari segi format (bentuknya), maka dapat dikategorikan pada tiga bentuk yaitu dakwah bi al-lisan, bi al-kitabah dan bi al-hal.

Dakwah bi al-lisan - tabligh merupakan salah satu bentuk pengajakkan para Nabi dan Rasul dalam kegiatan dakwahnya kepada umatnya. Hal ini dibuktikan dengan banyaknya ayat yang ditemukan dalam al-Qur'an yang menggunakan kata-kata tabligh dalam berbagai versi seperti ballaghayuballighu, tabllighan dan sebagainya. Ungkapan ini dapat ditemukan dalam surat An-Niasa' ayat 63, al-Maidah ayat 67, dan 99, al-An 'am ayat 19, Ali Imran ayat 20, al-Araf ayat 62,68, 93, Ibrahim ayat 52, An-Nahl ayat 35, 82, an-Nur ayat 54, Yasin ayat 17 , Ghafir ayat 80 dan lain-lain.

Jika dicermati secara mendalam pendapat Abu Bakar Aceh tentang terminologi dakwah, maka dapat dipahami bahwa dakwah merupakan usaha mengajak manusia supaya masuk ke dalam jalan Allah (sistem Islam) secara menyeluruh baik dengan lisan dan tulisan maupun dengan perbuatan sebagai ikhtiar muslim mengwujudkan ajaran Islam menjadi kenyataan dalam kehidupan syiasah (politik), usrah (keluarga), jamaah dan umat dalam semua segi kehidup-an secara berjamaah (terorganisasi) sehingga tewujud khairu ummah.

Amin Abdullah dalam Wahidin Saputra, mengemukakan bahwa ada tiga tahap dalam berdakwah yang terdiri terdiri dari preaching (pentablihgan), healthing (penyembuhan) dan judging (penghakiman). Menurut (Amin), tahapan dakwah Islam selama ini melompat dari pentablighan langsung ke penghakiman tanpa melalui penyembuhan. Dengan demikian, proses dakwah belum menyentuh penyelesaian problem yang dihadapi umat (Wahidin Saputra, 2012: 123)

Menurut teori tahapan dakwah, Wahidin mengemukakan bahwa Rasulul-lah Saw dan para sahabatnya telah berdakwah dalam tiga tahapan meliputi tahapan takwin, tanzhim dan taudi. Pada tahap pertama dilakukan dalam bentuk internalisasi dan sosialisasi ajaran taubidi yang dimulai dari ittishal fardhi-ijtimai (keluarga terdekat dan masyarakat). Kegiatan utama pada tahap ini adalah dakwah bi al-lisan (tabligh) dan dakwah bi al-hal (pengembangan masyarakat) seperti direpresentasikan dengan baitul aqabah. 
Inti dari baiat ini adalah sepakat untuk membentuk masyarakat kecil berbasis komunitas dalam mewujudkan masyarakat yang khairu al-Ummah. Pada tahap kedua adalah tanzhim-penataan dakwah. Tahap ini dilakukan dalam bentuk institusionalisasi Islam—pelembagaan dakwah. Akhirnya melahirkan piagam Madinah. Pada tahap ketiga disebut dengan tanfizh atau taudi (pelepasan dan kemandirian).

Al-Maraghi dalam tafsirnya menjelaskan kata-kata balighan (tabligh) dalam surat an-Niasa` ayat 63 (qaulan baligha) bermakna kata-kata yang dapat menggugah perasaan dan mempengaruhi jiwa. Proses tabligh yang dilakukan dimulai dari menghindari, menasihati dan memberikan katakata yang menyentuh perasaan (penyadaran). Ala Uddin Ali bin Muhammad Ibrahim bin Umar Syaikh Abu Husain dalam tafsirnya Lubabu alTakwili fi maani al-Tanzil yang dikenal dengan Tafsir Khazin mengemukakan bahwa kata-kata qaulan balighan dalam ayat 63 dari surat Annisa' mengandung pengertian perkataan yang membekas dan berpengaruh di hati. Qaulan balighan ditujukan untuk menghadapi kaum muanfiqin.

Menurut tafsir ini pula sebagian ulama berpandangan bahwa balighan adalah kata-kata yang menggugah hati yang ditandai dengan beberapa indikator antara lain;

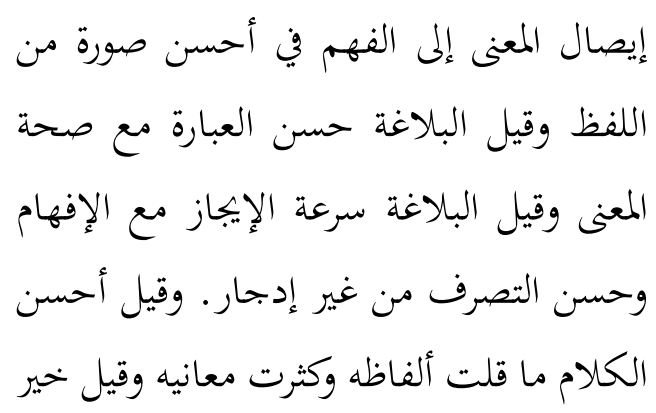

$$
\text { الكلام ما شوق أوله إلى سماع آخره }
$$

1. Maknanya dapat dipahami dengan baik melalui lafal yang baik,

2. Ungkapan yang baik dengan makna yang benar

3. Ungkapan yang singkat dapat dipahami, tepat dan tidak membosankan

4. Ungkapan yang singkat padat makna

5. Perkataan yang awalnya menarik hati sampai akhir pembicaraan,

Dengan demikian setiap perkataan para mubaligh akan mempengaruhi para pendengar atau umat yang mendegarkan isi dari pembicaraanya. Oleh karena itu seorang mubaligh seharusnya memperhatikan inti pembica-raannya. Hal ini sangat erat hubungannya dengan Qs. Az-Zumar ayat 18 :

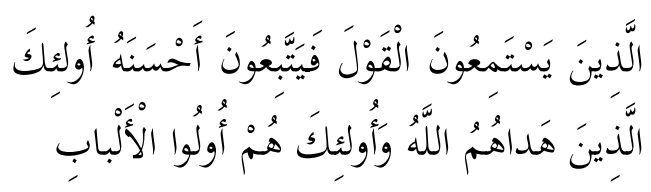

Orang-orang yang mendengarkan perkataan dan mereka yang mengikuti perkataan yang terbaik dari apa yang mereka dengar, mereka itulah orang-orang yang mendapat petujuk dari Allah dan mereka itulah orang-orang yang berfikir.

Ayat ini, menurut Ibnu Katsir dalam tafsirnya berkaitan dengan sifat orang-orang yang tidak menyembah berhala yang selalu taat dalam menyembah Tuhan Yang Maha Pemurah. Mereka inilah yang mendapat berita gembira dalam kehidupan dunia dan akhirat. Mereka itu adalah orang-orang memahami dan mengamalkan apa yang dipesankan kepadanya secara istiqamah (alA`raf: 145) dan mereka inilah yang memperoleh 
petunjuk dari Allah dan pada akhirnya mereka ini pulalah yang disebut dengan orang-orang yang berakal sehat dan berfitrah lurus.

Kemudian dalam pola komunikasi teori model Lasswell (1948), dapat dipahami bahwa komunikasi yang sederhana dan sering digunakan oleh orang yakni siapa(Who), berbicara tentang apa (says What), dalam saluran yang mana (whit chanel) kepada siapa (to whom) dan pengaruhnya seperti apa (what the effect) (littlejhon, 1996).

Dengan demikian tabligh sebagai proses pengkomunikasian ajaran Islam, maka unsurunsur komunikasi akan selalu melekat pada kegiatan tabligh yang meliputi mubaligh (who), pesan atau materi tabligh (Says What), Muballagh (penerima tabligh) (to whom)), media yang digunakan (chanel) dan pengaruh atau atsar (effect). Semua aspek atau komponen ini meruapakan satu kesatuan yang berkaitan dan berhubungan erat dalam satu makna komunikasi.

Jadi tabligh yang dilakukan oleh mubaligh tidak terlepas dari komponen-komponen tabligh yang merupakan suatu sistem dakwah meliputi mubaligh (subjek), muballagh (objek), maudhu’ atau maddah tablig ( materi), manhaj atau ushlub al-attabligh (metode) dan wasailul tabligh (media) serta wa atsar (efek) tabligh.

\section{METODE DAN PENDEKATAN}

Penelitian ini menggunakan metode kualitatif pendekatan deskriptif atau penelitian naturalistic. Penelitian ini menggambarkan apa adanya terkait dengan kegiatan mubaligh dalam menyajikan materi tabligh yang berhubungan dengan tematema social capital (modal sosial) masyarakat. Kegiatan tabligh yang dimaksudkan di sini adalah khutbah, ceramah, taushiyah dan kegiatan wirid lainnya baik yang bersifat mingguan maupun bulanan (Sugiyono, 2011: 283)

Penelitian ini dilaksanakan di tiga kecamatan yaitu Kecamatan Kuranji, Padang Barat dan Padang Timur yang didasari pada sebuah pertimbangan ilmiah yaitu berkesinambungnya kegiatan tabligh pada masjid-masjid di lokasi yang diteliti. Informan atau narasumber dalam penelitian ini adalah para mubaligh yang aktif melakukan kegiatan tabligh di berbagai masjid di kecamatan yang dipilih di kota Padang. Aspek yang diteliti dari informan adalah materi ceramah atau isi yang disajikan, cara penyajian serta alasan para mubligh dalam memilih dan menetapkan tema tablighnya.

Teknik pengumpulan data dilakukan dengan menggunakan teknik pur-posive. Penelitian ini dilaksanakan dengan cara menentukan dan menetapkan informan atau sumber atas dasar pertimbangan-pertimbangan tertentu. Alat yang digunakan dalam pengumpulan data adalah observasi dan wawancara. Observasi dilakukan untuk mengamati langsung kegiatan tabligh yang dilaksanakan oleh para mubaligh meliputi proses, cara penyajian materi tabligh, sedangkan wawan-cara digunakan untuk menggali lebih dalam informasi yang belum terjawab melalui pengamatan seperti alasan para mubaligh dalam memilih dan menetapkan tema tablighnya. Alat pengumpul data ini disusun secara sitematis melalui pedoman wawancara.

\section{ANALISIS TEMUAN PENELITIAN}

Berdasarkan hasil observasi dan wawancara terhadap kegiatan mubaligh kota Padang dari Juli 
s/d Oktober 2016. Maka dapat dikemukakan bahwa kegiatan tabligh di Kecamatan Kuranji dilaksanakan di masjid Raya Ampang dan masjid Nurul Huda Ketaping dan Al-Bahri Parak Jigarang. Kegiatan di samping Khutbah Jum at juga melaksanakan wirid mingguan pada setiap Jum at malam (masjid Nurul Huda) dan malam Minggu (masjid Raya Ampang). Padang Timur dilaksanakan di masjid Babussalam Sawahan Dalam dan masjid Baiturrahman Jati Dalam. Di masjid Babussalam Sawahan Dalam kegiatan wirid dilaksnakan pada setiap waktu kecuali hari Selasa dan Sabtu, sedangkan untuk masjid Baiturrahman Jati dilaksanakan pada setiap hari Senin, Rabu dan Jum `at. Padang Barat di masjid Sahara Padang Pasir dan masjid al-Wustho di Jalan Veteran Padang. Kegiatan wirid dilaksanakan pada setiap Juma'at malam.

Berdasarkan hasil observasi kegiatan tabligh dari Juli-Oktober 2016 di berbagai masjid di atas, maka ditemukan 10 orang mubaligh yang dipandang memenuhi persyaratan dan masuk kategori yang membahas tema-tema tabligh yang mengarah pada modal sosial (social capital) masyarakat. Pembahasan modal sosial disajikan dalam berbagai tema dan judul serta sistem penyajian yang berpariatif. Ada yang fokus dari awal penyajian sampai akhir secara rinci, dan tidak sedikit pula para mubaligh menyinggung tema yang dimaksudkan dalam penggalan-pengalan ceramahnya.

IS (49) dalam khutbah Jum `atnya mengungkapkan bahwa Islam sangat mengajurkan umatnya untuk hidup peduli terhadap kondisi kehidupan orang lain. IS, mengutip ayat suci al-Qur`an surat al-Ma`un. Metode penguraian materi khutbah yang diterapkan oleh IS adalah metode kisah dan ibrah. Is menegaskan bahwa banyak orang yang tahu agama (agamis) namun tidak spritualis. Spritualis dimaknai dengan kemampuan dalam mengamalkan dan menerapkan serta menjiwai nilai-nilai keagamaan dalam kehidupan. Spritualis tidak hanya larut dengan simbol-simbol keagamaan namun dirasakan manfaatnya dan diamalkan dalam kehidupan keseharian serta adanya rasa kepedulian terhadap orang lain.

MBA(48), mengaitkan kepedulian terhadap orang lain salah satu implementasi dan indikator dari jiwa atau rohani yang sehat. MBA mengemukakan bahwa "Salah satu tanda ibadah diterima oleh Allah disamping menenangkan batin bagi pelakunya juga tumbuhnya kesadaran beribadah baik ibadah khusus maupun umum serta adanya kepedulian kepada orang-orang yang membutuhkan melalui tenaga, pikiran, harta dan melalui pangkat, rezki atau bisa juga dengan menggunakan ilmu yang berorientasi amal shaleh dan menenangkan batin. Sebagai rujukan ceramah-wirid mingguan ini MBA mengambil petikan ayat dalam surat Arrum : 30, dengan judul tanda-tanda amal ibadah diterima oleh Allah Swt.

ZL(50), mengangkat tema ceramahnya dengan nilai-nilai ketakwaan yang mesti dipertahankan dalam kehidupan pascaRamadhan. Setidak-tidaknya ada tiga nilai ketakwaan yang mesti dilestarikan seperti hidup berguna dan selalu menjaga silaturrahmi.

MI(48) mengemukan bahwa salah satu bentuk nyata dari aplikasi kepedulian kepada masyarakat adalah mengimarahkan masjid yang telah didirikan. Kegiatan yang dapat dilakukan 
secara bersama adalah menghidupkan kegiatan masjid sebagai sentra kegiatan keaagmaan dalam memperbaiki akhlak genarasi muda. Salah satu tantangan yang merusak tatanan akhlak remaja adalah play station, telivisi dan hiburan lainnya. Untuk ke depan direncanakan kegiatan pembinaan generasi muda dengan melibatkan para mahasiswa di lingkungan masjid untuk melaksanakan pelatihan keterampilan penyelenggaraan jenazah serta menghidupkan kembali TPQ.

ZW(46) megemukakan perlunya tolongmenolong dalam menyelamatkan generasi dari kehancuran. Kondisi sekarang sangat meprihatinkan karena banyak generasi muda yang tersesat jalan dan kondisi iman yang lemah. Untuk itu setiap orang tua, guru, pemuka masyarakat perlu bersinergi untuk menyelamatkan mereka. Untuk menyelamatkan generasi muda dari ketersesatan jalan dan iman yang lemah, ZW menegaskan perlunya mengfungsikan secara baik empat rumah yaitu rumah ibadah, rumah tangga, rumah sekolah dan rumah adat.

EF(47) mengemukakan pula bahwa salah satu bentuk kepedulian itu melalui ibadah qurban. Berqurban salah satu wujud dari syukur kepada Allah atas segala limpahan rahmat-Nya kepada manusia. Bersyukur juga berarti menggunakan nikmat yang diberikan Allah dengan memperbanyak tahmid, menggunakan nikmat untuk mencari rezki melalui jalan yang halal dan berbagi dengan fakir miskin, memperbaiki kultur sosial kemasyarakatan melalui infaq, zakat, dan sadaqah. Kemudian sekali setahun melakukan berqurban pada hari Tasyrik.

ZH(41) megemukakan bahwa upaya penguatan mentalitas umat dapat dilakukan dengan meumbuhkembangkan rasa saling menghargai, saling mem-percayai dan mengedepankan aspek kepentingan bersama di atas kepentingan pribadi dan golongan. Kemudian perlunya dipelihara rasa tangung jawab dan rasa memiliki dalam hidup, baik basurau, banagari, berbangsa maupun bernegara.

Eli(48) mengemukakan bahwa kepedulian terhadap sesama terkait dengan kepedulian orangorang terhadap sesama ketika ditimpa musibah seperti musibah kematian. Kepedulian yang diharapkan adalah adanya terbangun rasa tolongmenolong dalam kehidupan termasuk bersegera dalam menyelenggarakan jenazah.

UW(41) membahas berbakti kepada orang tua dan hidup tolong menolong. UW lebih fokus kepada penguraian ayat-ayat dan hadis yang berkaitan dengan birrul walidaini dan kurbatun. Dalam penyajian tentang berbakti kepada orang tua dan hidup bermasyarakat mulai dari hidup bertetangga dan seterusnya merupakan hal yang sering diungkapkan oleh Rasulullah Saw dan menjadi sesuatu yang aktual dibicarakan.

$\operatorname{MDM}(62)$ memilih tabligh tematik dalam bentuk pengajian tafsir tentang tauhid. Bagi MDM persoalan tauhid hal yang perlu dan diutamakan karena apapun persoalan kehidupan dan fenomena yang ada ini tergantung pada kualitas tauhid.

\section{Tema-tema Tabligh}

Berdasarkan wawancara secara umum para mubaligh mengangkat tema tabligh yang berkaitan dengan modal sosial masyarakat (social capital) antara lain membahas tentang kepedulian, membangun kebersamaan, silaturrahim dan kepekaan sosial. Secara khusus para mubaligh 
mengakat tema-tema yang aktual yang bersifat situasional di lokasi mereka bertabligh.

MBA mengungkapkan bahwa tema yang sering diangkatkan adalah tentang kesadaran diri dan kehambaan serta kesadaran hidup untuk tolong -menolong, hidup berbagi dan peduli. Kepedulian ini diwujudkan dalam bentuk tolongmenolong melalui fikiran, tenaga dan harta.

Eli mengemukan bahwa tema yang sering diangkatnya adalah peduli terhadap jenazah. Peduli terhadap jenazah adalah bagaimana terciptanya nuansa tolong-menolong dan kepedulian dalam wujud unjuk kerja dalam menyeleng-garakan jenazah warga di mana ia berada.

MI menjelaskan bahwa tema yang sering diangkat dalam kegiatan tabligh adalah motivasi gemar berinfaq dan bersedekah, kerelaan menjadi penolong, hidup bertenggang rasa dan saling menghargai serta rasa peduli terhadap tetangga dan masyarakat.

UW mejelaskan bahwa tema yang paling sering diangkat dan dijadikan sebagai materi dalam mengembalikan nilai-nilai luhur yang dianut oleh masyarakat Minangkabau adalah berbakti kepada orang tua, etika bergaul mudamudi dan hidup saling membantu.

$\mathrm{ZH}$, mengemukakan bahwa tema-tema yang sering diangkatkanya adalah kepedulian kepada masjid—mengimarabkan masjid, penataan ibadah shalat. Menurutnya apabila kualitas shalat telah baik, maka kehidupan pribadi dan sosialnya juga ikut baik, karena pada hakikatnya sahalat mengajarkan kita hidup punya Standar Operational Procedure.

DM, menyatakan bahwa tema tabligh yang sering diangkatnya lebih konsen kepada tauhid.
DM beralasan bahwa ketika tauhid seseorang telah benar, baik dan kuat, maka nilai-nilai luhur seperti hidup penyantun, penyanyang,jujur, toleransi, saling menghargai dengan sesamanya otomatis mudah diwujudkan. Sebaliknya ketika tauhidnya masih rapuh dan lemah, maka nilai-nilai tersebut tidak akan berpengaruh dalam kehidupannya.

\section{Pendekatan Tabligh}

MBA dalam bertabligh menggunakan pendekatan sosiologis dan psikologis. Kemudian dalam pemaparannya lebih banyak menggunakan teknik dialogis atau tanya jawab. Menurutnya cara ini sangat efektif dan memudahkan bagi jamaah dalam memahami isi ceramah.

Eli mengemukan bahwa pendekatan yang digunakannya dalam tabligh adalah menggunakan pendekatan budaya dan agama serta mengkolaborasikan antara konsep teori dan praktik.

MI mengungkapkan bahwa pendekatan dan metode tabligh yang digunakannya adalah pendekatan sosial atau sosiologis serta pemberdayaan masyarakat, sedangkan metode yang sering digunakan adalah muzakarah,dan mubahasah.

UW memaparkan bahwa pendekatan dan teknik penyajian yang diterapkannya dalam kegiatan tabligh lebih memilih pendekatan maudhu'i. Maudu'i yang dimaksudkan adalah materi dikemas dan disajikan berdasarkan tematema aktual dan peristiwa-peristiwa yang terjadi dalam ke seharian masyarakat. Peristiwa-peristiwa tersebut dirangkum dalam materi ceramah. Sementara penyajiannya lebih mengedepankan tanya jawab (al-asilah wal ajwibah) yang dimulai dari pemaparan ayat atau hadis kemudian membuka termin tanya jawab. 
ZH menggunakan pendekatan sosial budaya dengan metode tanya jawab. Menurut $\mathrm{ZH}$, orang Minang itu unik dan cara itu sangat menentukan. Orang Minang-khususnya pemuka masyarakatnya memberikan nasihat "Kok Gadang indak malendo, kok cadiak indak manjua, hati-hati nan di ateh di bawah kamaimpok". Dalam menjelaskan atau mensyarahkan suatu tema tabligh ZH mengemukakan "saya sangat berhatihati dalam menyampaikan sesuatu kepada siapa materi ini saya sajikan”.

MD dalam tablighnya menggunakan pendekatan dan metode tanya jawab. Menurutnya cara ini sangat efektif untuk memahami ayatayat dan hadis yang berkaitan dengan tauhid. Kemudian tidak jarang melakukan perdebatan.

\section{Alasan Pemilihan Tema Tabligh}

Pemilihan tema menurut MBA dikarenakan permintaan jamaah atau bisa juga dikarenakan hasil analisis terhadap peristiwa-peristiwa aktual yang terjadi di tegah-tengah masyarakat yang memerlukan solusi atau pemecahan bersama melalui ajaran agama.

Eli beralasan dalam pemilihan dan penetapan tema "peduli jenazah" sebagai icon tablighnya didasari kepada permintaan masyarakat serta ditemu-kannya di lapangan banyak orang yang ketakutan atau menghindar untuk menyelenggarakan jenazah dengan berbagai alasan. Adapun alasan yang sering ditemukan adalah takut kepada mayat, tidak tahu bagaimana kaifiyat dalam penyelenggaraan jenazah.

MI memiliki alasan logis tentang pemilihan tema tentang filanteropi (semangat senang berinfaq-berbagi) diawali oleh kondisi sosial masyarakat kota Padang dan umumnya masyarakat
Minangkabau, bahwa disadari atau tidak, nilainilai luhur yang dipegang dan diwariskan kepada anak kemenakannya sudah mulai terkikis oleh tantangan zaman. Kini kepedulian, rasa kegotongroyongan, hidup berbagi dan bekerjasama sudah dirasakan mulai asing dalam kehidupan masyarakat. Masyarakat ketika diminta goro tidak banyak yang hadir, jika ada kemalangan seperti wafatnya salah seorang warga tidak banyak orang yang mau dan bisa menyelengarakan jenazah. Ini perlu ditinjau ulang kembali dan diperbaiki agar nilai-nilai mulia tersebut bisa dilestarikan. Masyarakat Minangkabau sangat kental dengan slogan "Adat basandi syara',syara' basandi kitabullah". Ungkapan ini memberi peluang bahwa nilai-nilai luhur yang dimiliki oleh para orang tua kita tidak bertentangan dengan nilai-nilai agama yang perlu diamalkan dalam masyarakat.

UW beralasan untuk menyikapi fenomena dalam keseharian masyarakat yang harus dicarikan dan ditemukan jalan pemecahannya. UW mengemukakan bahwa orang Minang dahulu sangat hormat dan santun kepada orang tua, sangat menjaga etika pergaulan. Orang Minang merasa malu ketika berjalan dengan lawan jenis yang bukam mahramnya. Begitu juga dalam keseharian rasa tenggang rasa, hidup tolong-menolong saling membantu menjadi model dan modal sosial yang membuat mereka terkenal. Lain halnya dengan sekarang, nilai-nilai itu sudah mulai hilang dan perlu untuk dikembalikan dan diperkenalkan kembali kepada generasi muda. Mengembalikan yang sudah ada jauh lebih efektif daripada membuat yang baru atau yang belum ada.

ZH memilih tema didasarkan atas pertimbangan bagaimana mengem-balikan nilai- 
nilai luhur masyarakat Minangkabau yang sudah mulai dirasakan hilang. Saya memahaminya (kata $\mathrm{ZH})$ bahwa berdasarkan observasi sederhana di masjid-masjid Minangkabau ditemukan bahwa telah terjadi pergeseran nilai dalam budaya Minangkabau sendiri. Kalau dahulu masjid dan surau dibangun atas dasar kebutuhan dan digerakkan dengan partisipasi masyarakat, kini masjid dibangun oleh para donatur dan diborongkan kepada tukang tertentu. Akhirnya rasa memiliki secara perlahan mulai lenyap. Oleh karena itu, tema ini penting sebagai langkah awal dari sebuah perubahan melalui masjid.

MD mengemukakan alasan kenapa dia mengambil tema tauhid dalam kegaiatan tablighnya diadasari atas alasan yang sangat sederhana yaitu "aw-waludin ma 'rifatullah" katakata ini menurutnya" al-din " bukan saja agama akan tetapi semua aturan kehidupan.

\section{Analisis Temuan Tema Tabligh}

Berdasarkan tema di atas (observasi) terkait dengan penampilan mubaligh dalam menyajikan materi tablighnya dapat dikemukakan bahwa secara umum para mubaligh mengangkat tema yang memiliki kemiripan antara mubaligh yang satu dengan mubaligh lain, walaupun arah pembicaraan berbeda. Kemiripan yang dimaksud adalah kebanyakan mubaligh mengusung tema kepedulian dan tolong menolong dan bekerja sama. Hasil pengamatan menunjukkan bahwa para mubaligh membahas tema-tema yang berkaitan dengan nilai-nilai yang menjurus kepada sosial capital.

Secara umum pemaparan materi tabligh dapat ditegaskan bahwa sebagian besar dari mubaligh tidak menyebutkan judul dan arah pembahasan yang bersifat mengikat dan membangun minat pendengar. Hanya sebagian kecil dari mubaligh yang sengaja memberi judul ceramahnya seperti hidup tolong menolong. Sedangkan sebagian besar mubaligh menyinggung tolong menolong dan peduli kepada orang lain melalui penjelasan atau penjabaran tentang indikator dari orang yang bertakwa dan sebagainya. Bahkan ada pula muabligh yang hanya menyebut-kan istilah tolong-menolong dan peduli pada orang lain tanpa mengemukakan kiat dan strategi penerapannya.

Semestinya menurut hemat penulis, tematema yang dipilih oleh mubaligh dipertegas dengan penetapan judul yang menarik. Judul yang baik adalah sinkron dan relevan dengan tema aktual yang disajikan. Judul sebaiknya disebutkan di awal pembicaraan yang didukung oleh dalildalil yang relevan dengan tema. Kemudian untuk menarik perhatian para pendengar sebaiknya mubaligh member-kan arah pembicaraanbatasan penguraian secara terfokus dengan penguraian yang sistematis sesuai dengan pokok persoalan. Misalnya jika seorang mubaligh menetapkan judul " hidup tolong menolong” maka arah atau fokus pembicaraan tersebut dibatasi kepada pengertian tolong menolong, alasan kenapa perlu hidup saling menolong, dalil-dalil yang berhubungan dengan prinsip perintah dan anjuran hidup saling menolong serta efek dari tolong menolong dalam membangun keutuhan hidup bermasyarakat. Dengan demikian dapat diambil suatu pemahaman bahwa ada indikasi mubaligh membahas modal sosial masyarakat melalui tablighnya dengan judul tolong-menolong dan membangun kepedulian walaupun pembahasannya belum maksimal sesuai dengan apa yang diharapkan. 
Penetapan tema dapat dikemukan bahwa masing-masing mubaligh memiliki alasan logis, praktis dan filosofis terkait dengan tema yang diusungnya. Penetapan tema kebanyakan dibuat berdasarkan hasil pengamatan dan peng-alaman para mubaligh dalam menjalankan tugas-tugas dakwahnya di lapangan. Kemudian disamping pengamatan pendahuluan sebelum bertabligh, untuk memperkuat dan memperkaya bahan bacaan sebagian mubaligh juga meman-faatkan media cetak sebagai bahan dan acuan dari tablighnya. Dengan demikian dapat ditarik suatu pemahaman bahwa penetapan suatu tema sangat ditentukan dan dipengaruhi oleh situasi dan kondisi atau femomena yang terjadi bersifat kekinian di tengah-tengah masyarakat. Peristiwa kekinian yang masih hangat atau aktual di tengah-tengah masyarakat menarik untuk diangkat karena peristiwa itu masih segar dalam ingatan mereka. Sungguhpun demikian akan lebih baik menurut penulis seorang mubaligh dalam menetapkan tema tablighnya tidak sekedar mempertimbangankan aspek aktualitas, fenomenal, namun juga memper-hatikan aspek kebutuhan dari masyarakat. Itulah makanya sebelum melakukan dan menyajikan materi tabligh seyogyanya materi tersebut hasil dari analisis kebutuhan masyarakat melalui proses ilmiah.

\section{Pendekatan dan Teknik Penyajian}

Pendekatan dan teknik penyajian materi tabligh yang dilaksanakan oleh mubaligh, berdasarkan observasi dan wawancara dapat dikemukakan secara umum pendekatan sosiologis menjadi pendekatan umum para mubaligh disam-ping pendekatan antropologis serta teologis. Pendekatan sosiologis dimaknai dengan pendekatan yang digunakan oleh para mubaligh mengacu pada fenomena sosial kemasyarakatan yang berkembang. Sedangkan pendekatan antropologis dimaknai dengan pendekatan melalui budaya setempat dan pendekatan teologis dimaknai dengan pendekatan berbasis keyakinan. Kemudian dari teknik yang digunakan para mubaligh dalam tablighnya bervariasi mulai dari dialogis, monologis dan debat serta aplikasi.

Berdasarkan pengamatan persoalan dalam penyajian sebagian besar mubaligh belum fokus mengkaji sebuah tema secara tuntas. Mulai dari pemberian judul, penegasan ayat dan hadis, arah pembahasan, uraian yang fokus serta kesimpulan. Dengan demikian dapat dikemukakan bahwa sistematika penyajian para mubaligh agaknya perlu menjadi perhatian lebih serius untuk efektivitas dari sebuah tabligh.

Berdasarakan hal itulah, menurut penulis mubaligh sebaiknya membatasi pembicaraannya sesuai dengan judul yang dissitematiskan sedemikian rupa. Isi pembicaraannya mengacu pada batasan-batasan uraian yang telah disiapkan, sehingga dengan demikian ungkapan dan ucapan mubaligh akan terarah dan menggugah, singkat, padat, akurat dan membawa manfaat atau fadhilah bagi yang mendengar.

\section{Alasan Pemilihan Tema}

Alasan para mubaligh memilih tema bardasarkan wawancara dengan para mubaligh, secara umum dapat dikemukan bahwa para mubaligh telah memenuhi standar dalam member alasan dalam pemeilihan tema tabligh. Alasan yang paling mendasar adalah kebutuhan dan keprihatinan para mubaligh terhadap fenomena kehidupan yang terjadi dalam masyarakat lingkungan dimana tabligh itu digelar. 
Nilai-nilai kehidupan masyarakat Minang khususnya kota Padang yang dahulunya dipertahankan dan menjadi nilai yang dirujuk, kini tinggal slogan" adat basandi syara', syarak basandi kitabullah, syara' mangato adaik mamakai. Barek samo dipikua, ringan samo dijinjiang, sahilia samudiak saayun salangkah. Bulek aia dek pambuluah, bulek kato dek mupakiak. Kok bulek dapek digolongkan kok picak dapek dilayangkan. Lamak dek awak katuju dek urang. Sanasip saparasaian, salapiak sakatiduran"

Ungkapan di atas bagi sebagian mubaligh tinggal hiasan bibir dan penghias kata para penghulu dalam resepsi kegiatan adat istiadat atau pemanis kata para mubaligh. Realnya di lapangan sulit untuk ditemukan. Di sisi lain alasan para mubaligh mengangkat tema-tema ini karena permintaan langsung dari masyarakat melalui pengurus masjid serta ada juga yang beralasan spesifik keahlian mubaligh itu sendiri dipengaruhi oleh ilmu dan pengalaman mereka sebagai bahagian dari penggerak perubahan dalam masyarakat.

Dengan demikian dapat ditegaskan bahwa para mubaligh dalam kegiatan tablighnya menetapkan sebuah tema dan menyajikan dalam sebuah penguraian telah memiliki alasan logis, ilmiah dan menggambarkan bahwa mubaligh memiliki visi dan misi yang jelas yaitu perubahan dan perbaikan kondisi umat menuju umat yang terbaik dan sejahtera.

Jika dicermati proses dan pentahapan yang dilakukan oleh mubaligh, maka dapat dikatakan bahwa tabligh yang dilakukan mereka telah mengacu kepada konsep pengembangan masyarakat Islam. Amin Abdullah dalam Nanih meng-ungkapkan bahwa pengembangan masyarakat Islam adalah sistem tindakan nyata yang menawarkan alternatif model pemecahan masalah ummah dalam bidang sosial, ekonomi, dan lingkungan dalam perspektif Islam.

Nanih lebih lanjut mengemukan bahwa kegiatan Pengembangan masya-rakat Islam terdiri dari kegiatan pokok berupa transformasi dan pelembagaan ajaran Islam ke dunia realitas Islam melalui; penyampaian konsepsi Islam mengenai kehidupan sosial, ekonomi, dan pemeliharaan lingkungan, peng-galangan ukhuwah Islamiah lembaga umat dan kemasyarakatan, menjalin dan mewujudkan berbagai MoU dengan berbagai kekuatan masyarakat, riset potensi lokal, katalisasi aspirasi dan kebutuhan umat, konsultasi dan pendampingan teknis, dan mendampingi penyususnan rencana dan aksi sosial serta memandu pemecahan masalah dan melakukan stabilisasi .

Kemudian Abdul Munir Mulkan (Teologi Kebudayaan) sebagaimana yang dikemukakan oleh Nanih bahwa konsep dan strategi dakwah harus diarahkan pada pemecahan berbagai persoalan yang dihadapi oleh masyarakat di lapangan. Dakwah yang diharapkan adalah menghasilkan tiga kondisi yang meliputi tumbuhnya kepercayaan dan kemandirian umat serta masyarakat yang bersikap optimis. Kemudian tumbuhnya kepercayaan terhadap kegiatan dakwah guna mencapai tujuan kehidupan yang ideal, serta berkembangnya kondisi sosioekonomi-budaya, politik-iptek sebagai landasan peningkatan kualitas hidup.

Dengan demikian dari apa yang dilakukan oleh mubaligh dalam melesterikan nilai-nilai luhur yang dahulunya telah pernah ada dan dipedomani 
melalui pemberian informasi-pengarahan melalui tablighnya, dari perspektif konsep pemberdayaan masyarakat telah melakukan satu langkah kegiatan penguatan modal sosial yang cenderung mulai menipis dan melemah.

Setidak-tidaknya menurut penulis dari yang dilakukan mubaligh; mengamati dan menggali kebutuhan umat, menyusun naskah tabligh sesuai dengan tema-tema aktual yang memerlukan pemecahan merupakan sesuatu langkah yang perlu diapresiasi. Usaha ini telah mengacu kepada sebuah proses peningkatan dan pelestraian nilai-nilai yang terkesan mulai menghilang dan kurang mendapat perhatian dalam pelestariannya sebagaimana yang dingkap oleh para mubaligh dalam wawancara.

Sungguhpun demikian secara ilmiah perlu diteliti tentang nilai-nilai sosial apakah benar telah tergerus dan terkikis serta nilai-nilai mana yang terkikis dan apa yang mengikisnya. Oleh karena itu tinggal lagi bagaimana meninaklajuti kegiatan tabligh dalam bentuk pemberian informasi kepada masyarakat yang berkelanjutan dalam format aksi nyata dalam melestarikan nilai-nilai yang akan menjadi modal sosial dalam kehidupan masyarakat.

\section{KESIMPULAN}

Dari penjelsan sebelumnya dapat disimpulkan bahwa tema-tema tabligh yang berhubungan dengan modal sosial (social capital) masyarakat yang disampaikan oleh mubaligh dalam bentuk pemberian informasi-penyajian materi melalui cermah, khuthbah dan wirid pengajian di berbagai masjid di kota Padang. Adapun tema-tema tabligh yang diangkat berkaiatan dengan modal sosial adalah hidup tolong menolong, membangun kebersamaan dan tanggung jawab serta kepedulian. Pendekatan yang digunakan oleh para mubaligh menggunakan pendekatan sosial budaya, pribadi dan praktik dengan teknik ceramah monologis, tanya jawab (dialoh) serta pemberian contoh. Alasan pemilihan tema oleh para mubaligh, secara umum didasri oleh pertimbangan hasil observasi dan hasil kajian tentang kebutuhan umat serta sebagian kecil berdasarkan permintaan masyarakat dan spesifikasi keahlian mubaligh itu sendiri serta inisiatif mubaligh.

\section{DAFTAR PUSTAKA}

Amin, M. Masyhur. (1995). Dinamika Islam (sejarah Transpormasi dan Kebangkitan. Yogyakarta: LKPSM.

Harun, Rochajat, dkk. (2011). Komunikasi Pembangunan Perubahan Sosial. Jakarta: Rajawali.

Hasim, dkk. (2009). Community Development berbasis Ekosistem Sebuah Alternatif Pembangunan Masyarakat. Jakarta: Diadid Media.

Machendraty, Nanih. (2001). Pengembangan Masyarakat Islam dari Ideologi, Strategi sampai Tradisi. Bandung: PT. Remaja Rosdakarya.

Maderista, Fuad. (2008). Fasilitasi Pemberdayaan Masyarakat_Strategi dan Proses Bekerja Berbasis Kelompok. Padang: Fak. Pertanian UNAND.

Muhddin, Asep. dkk. (2014). Kajian Dakwah Multi Perspektif. Bandung: PT. Remaja Rosdakarya. 
Putra, Nursa. (2011). Reseach Development, Penelitian dan Pengembangan Suatu Pengantar, Jakarta: Rajawali.

Sadiah, Dewi. (2015). Metode Penelitian Dakwah. Bandung: Rosdakarya.

Salihin, Nurus, dkk. (2015). Pemeta Masalah Kehidupan Beragama di Sumatera Barat, Padang. Imam Bonjol Press.
Sugiyono. (2011). Metode Penelitian Kualitatif. Bandung: Alfabeta.

Thibi, Bassan. (1991). Islam and Cultural Accomondation of Social Change. Wastivew Press. Bouder San Pransisko. 
